UDC $613 ; 614$

DOI: $10.21668 /$ health.risk/2019.4.02.eng

\title{
SOCIAL AND ECONOMIC DETERMINANTS AND POTENTIAL FOR GROWTH IN LIFE EXPECTANCY OF THE POPULATION IN THE RUSSIAN FEDERATION TAKING INTO ACCOUNT REGIONAL DIFFERENTIATION
}

\author{
N.V. Zaitseva ${ }^{1,2}$, G.G. Onishchenko ${ }^{3,5}$, A.Yu. Popova ${ }^{1,4}$, S.V. Kleyn ${ }^{2}$, \\ D.A. Kiryanov ${ }^{2}$, M.V. Glukhikh ${ }^{2}$
}

${ }^{1}$ Federal Service for Surveillance on Consumer Rights Protection and Human Wellbeing, 18, bld. 5 and 7

Vadkovskiy pereulok, Moscow, 127994, Russian Federation

${ }^{2}$ Federal Scientific Center for Medical and Preventive Health Risk Management Technologies, 82 Monastyrskaya Str., Perm, 614045, Russian Federation

${ }^{3}$ Russian Academy of Science, 32 Leninskii avenue, Moscow, 119334, Russian Federation

${ }^{4}$ Russian Medical Academy for Postgraduate Studies, 2/1 Barrikadnaya Str., Moscow, 123995, Russian Federation

${ }^{5}$ I.M. Sechenov First Moscow State Medical University, 8, bld. 2 Trubetskaya Str., Moscow, 119435,

Russian Federation

The article contains results of the research on a correlation between social and economic determinants and life expectancy of the RF population. The research is quite relevant at present as it is consistent with the goals set within the demographic policy in the RF, including searching for efficient tools aimed at solving tasks set in it and achieving its targets. Our research goal was to examine social and economic determinants and potential for a growth in life expectancy of the RF population taking into account regional differentiation.

We analyzed world experience in examining effects produced by social and economic factors on life expectancy. Correlationregression analysis allowed us to detect that economic parameters, lifestyle-related ones, and parameters reflecting education and home comforts were the most significant modifiers $\left(R^{2}=0.06-0.43\right)$. We showed that aggregated changes in these parameters equal to $10.0 \%$ could result in 460.5 days increase in life expectancy (1.3 years longer). The greatest contribution was made by population employment/unemployment taking into account their education (115.29 days); home comforts available in housing (86.9 days); economic parameters (74.09 days); psychosocial stress (54.58 days); alcohol drinks sales (49.57 days); basic food products consumption (46.23 days). These data are fully consistent with the already known results obtained by domestic and foreign researchers in the field and efficiently complement them. Our research results indicate that the current social policy that is being implemented in the $R F$ is quite relevant as it is aimed at reducing social and economic inequality and eliminating a social gradient as regards health of various population groups. We are also sure it is necessary to perform further research in the sphere.

Key words: life expectancy, social and economic factors, social gradient, demographic policy, population, life quality, morbidity, mortality, factor analysis, cluster analysis.

Nowadays in the Russian Federation life expectancy at birth (LEB) amounts to 72.6 years (2017); it is equal to 67.51 among males; and to 77.64 , among females. This gender-related discrepancy between men and women in the country (10.13) is unprecedented against the average world one (4.81) and the European one (6.67). According to the UN annual research "Life Expectancy Index 2018" Russia occupies the $116^{\text {th }}$ place among 191 analyzed

(c) Zaitseva N.V., Onishchenko G.G., Popova A.Yu., Kleyn S.V., Kiryanov D.A., Glukhikh M.V., 2019

Nina V. Zaitseva - Academician of the Russian Academy of Sciences, Doctor of Medical Sciences, Professor, Scientific Director (e-mail: znv@fcrisk.ru; tel.: +7 (342) 237-25-34; ORCID: https://orcid.org/0000-0003-2356-1145).

Gennadiy G. Onishchenko - The RAS Academician, Doctor of Medical Sciences, Professor, head of the Department for Human Ecology and Environmental Hygiene (e-mail: journal@fcrisk.ru; tel.: +7 (495) 954-39-85; ORCID: http://orcid.org/0000-0003-0135-7258).

Anna Yu. Popova - Doctor of Medical Sciences, Professor, Supervisor, Head of the Department for Sanitary-Epidemiologic Service Organization (e-mail: rmapo@rmapo.ru; tel.: +7 (499) 458-95-63; ORCID: https://orcid.org/0000-0002-4315-5307).

Svetlana V. Kleyn - Doctor of Medical Sciences, Associate Professor, Head of the Department for Systemic Procedures of Sanitary-Hygienic Analysis and Monitoring (e-mail: kleyn@fcrisk.ru; tel.: +7 (342) 237-18-04; ORCID: https://orcid.org/00000002-2534-5713).

Dmitry A. Kiryanov - Candidate of Technical Sciences, Head of the Department for Mathematic Modeling of Systems and Processes (e-mail: kda@fcrisk.ru; tel.: +7 (342) 237-18-04; ORCID: https://orcid.org/0000-0002-5406-4961).

Maksim V. Glukhikh - Post-graduate student, Junior researcher (e-mail: gluhih@fcrisk.ru; tel.: +7 (342) 237-18-04; ORCID: https://orcid.org/0000-0002-4755-8306). 
countries [1]. Life expectancy in 32 countries has already exceeded 80 years; however, it has not yet reached 70 in 63 countries. Contemporary forecasts made by the UN predict that, taking into account an average population mortality scenario in the RF, LEB in the country is likely to grow [2]. To a great extent it will depend on life quality improvement and an increase in living standards that are determined by such socioeconomic parameters as welfare, healthcare, education, employment, and lifestyle. According to the Clauses 2 and 7 of the RF Constitution, a person is the highest value for the state and the latter is obliged to create favorable conditions for his or her development and life ${ }^{1}$. Relevant policy in the economic and social spheres will provide a steady growth in LEB in the RF.

Implementation of the demographic policy in the RF is aimed at increasing population life expectancy, reducing mortality, birth rate growth, regulating internal and external migration, preserving and improving population health, and a consequent improvement in the demographic situation in the country. In this relation, The RF President Order issued on October 9, 2007 No. 1351 "On approval on The Concept of the demographic policy in the Russian Federation up to $2025^{\prime \prime 2}$ is well-grounded and relevant to the existing demographic situation; moreover, it is quite feasible and can truly provide an increase in population life quality in the RF. It fixes a wide range of tasks thus giving an opportunity to find solutions to priority problems including those aimed at se- curing population growth up to 145 million people and an increase in life expectancy of the RF population to 75 years up to 2025 .

A basic instrument that would allow implementing of the above-mentioned Order is the RF Government Order issued on April 14, 2016 No. $669-r^{3}$. This document states that life expectancy should reach 74 years by 2020 ; it also fixes there should be an increase in some other demographic parameters (population number, birth rate coefficient, and migration growth). All the implemented activities are aimed at reaching target quantitative parameters via improved population life quality and it has a key significance for the steady growth in population number in the country.

The RF President Message to the Federal Assembly issued on March 01, 2018 [3] stresses that it is important to preserve the country population including creation of favorable conditions for development, self-realization, and creative work for each person as it will help securing well-being for each citizen and the society as a whole. The state policy that is being implemented at the moment, including approval on new RF national projects (NP) entitled" : "The Human Capital", "Comfortable Living Environment", and "Economic Growth", is now aimed at achieving a strategic goal that is the RF becoming a member of a pool that includes " 80 plus" countries.

"Healthcare", and "Demography" are basic national projects that cover issues related to a growth in LEB. These two NPs fix different ways how to achieve LEB target levels but still

\footnotetext{
${ }^{1}$ The Constitution of the Russian Federation. Available at: http://www.constitution.ru/ (date of visit December 01, 2019).

${ }^{2}$ On approval on The Concept of the demographic policy in the Russian Federation up to 2025: The RF President Order issued on October 9, 2007 No. 1351. Garant. Available at: http://ivo.garant.ru/\#/document/191961/paragraph/1:0 (date of visit December 01, 2019).

${ }^{3}$ On approving an activity plan for the implementation in 2016-2020 of The Concept of the demographic policy in the Russian Federation up to 2025 that was approved by the RF President Order issued on October 9, 2007 No. 1351 " On approval on The Concept of the demographic policy in the Russian Federation up to 2025". KODEKS: an electronic fund of legal and reference documentation. Available at: http://docs.cntd.ru/document/420350355 (date of visit December 01, 2019).

${ }^{4}$ On national goals and strategic tasks of the Russian Federation development up to 2024: The RF President Order dated May 07, 2018 No. 204. The RF President official web-site. Available at: http://kremlin.ru/acts/bank/43027 (date of visit December 01, 2019).

${ }^{5}$ The Profile of "Healthcare" national project / improved by the Presidium of the RF President Council on strategic development and national projects (the meeting report dated December 24, 2018 No. 16). Garant. Available at: https://base.garant.ru/72185920/ (date of visit December 01, 2019).

${ }^{6}$ The Profile of "Demography" national project / improved by the Presidium of the RF President Council on strategic development and national projects, (the meeting report dated December 24, 2018 No. 16). Garant. Available at: https:// base.garant.ru/72158122/99f9dac8326542de16e0c46495ad0911/ (date of visit December 01, 2019).
} 
they supplement each other quite harmoniously. "Healthcare" NP solves the given task via developing primary medical and sanitary aid, providing medical organizations with highly qualified personnel, public healthcare digitalization, and implementation of innovative medical technologies into everyday medical practices. It all should eventually result in achieving target parameters related to a decrease in population mortality caused by circulatory system diseases and malignant neoplasms, including mortality among employable population. The main focus of the project is on solving issues related to secondary prevention such as preventing disease complications, disability among patients, and preventing lethal outcomes of diseases.

In its turn, "Demography" NP has a target to achieve an increase in healthy life expectancy up to 67 years; it solves issues related to improving life quality via stimulating citizens to make conscious decisions regarding their own health and, above all, via creating conditions for that. This project focuses on primary prevention aimed at preventing occurrence and effects produced by risk factors that can cause a disease. And here main efforts are aimed at supporting motherhood and childhood, improving life quality of elderly people, and creating stimuli for citizens of all ages to pursue healthy lifestyle.

At present a lot of attention is paid to examining possible ways how to increase and predict life expectancy, especially its healthy and active period $[4,5]$. In economically developed countries experts mostly try to find ways how to achieve a maximum possible increase in person's life together with preserving his or her basic physical and cognitive abilities. On the contrary, in developing countries it is still vital to increase LEB as an integral population parameter of population mortality. The difference between research performed in developed countries and developing ones is explained via current stages in society development according to the epidemiologic transition theory [6]. Developed countries are now at the fourth stage in this transition with all the properties that are typical for it: low population mortality, high LEB, chronic diseases prevalence in morbidity structure including aging-associated diseases such as Alzheimer's disease, senile asthenia, etc. At the same time in developing countries population suffer from diseases caused by industrialization and urbanization such as circulatory system diseases, oncologic diseases, environmentally induced diseases, and injuries. In some countries mass infections and hunger are still vital issues that need to be resolved [7]. Some researchers insist there was another stage in the process that occurred in Russia in 1990; the stage was called "a period of health deterioration and social upheavals" [8]. The stage was characterized with doubled diseases burden when deteriorated economic and social conditions led to an increase in mortality caused by infectious diseases, alcoholism, and injuries on the backgrounds of degenerative diseases; also a lot of diseases tended to occur at younger ages during that period.

Given all the above-mentioned, there are different ways how to increase LEB. For developed countries, a key issue here is to find causes of degenerative aging-associated diseases and ways how to treat them $[9,10]$. For developing countries, and the RF as well, the problem can be solved via drawing on experience accumulated by advanced countries as well as economic transformations aimed at improving life quality and reducing population mortality and morbidity [11].

Differences that exist in stages in epidemiologic transition are also confirmed by how fast LEB grows in different countries. Over the last 70 years LEB in developed countries has increased by $15.0 \%-20.0 \%$, growth rates being less than $1 \%$ over the recent years. Over the same time period, LEB in developing countries has increased by more than $60.0 \%$, and growth rates annually have exceeded $2 \%$ over the recent years. In the middle of the last century (1950es) LEB amounted to approximately 70 years in developed countries and it didn't exceed 55 years in developing ones [2]. Besides, in developed countries processes related to mortality reduction and, consequently, a growth in LEB were consistent and planned, and in developing countries a similar growth 
in LEB can result in accelerated demographic aging of a country population and disease burden being doubled; it requires completely different approaches to planning managerial activities [12, 13].

Such properties of a demographic process are rather generalized; a basic role in this case belongs to a state policy aimed at resolving given demographic tasks. For example, in 1960-1970es LEB in the RSFSR (Russia) was similar to that in the Western Europe. Over the next 20 years the parameter stagnated in the country, and in 1990es political, economic, and social transformations and consequent changes in structure and dynamics of population mortality and morbidity led to a decrease in LEB, especially among males and employable population. However, at present when the shock therapy on the country economy was completed and political and social stricture in the country is rather stable, changes in LEB have become positive and it has started to grow. In 2017 the parameter was equal to 72.7 years for the whole population [14], and, according to current data, in amounted to 73.7 years in the first half of 2019 [15]. Over the same period life expectancy has also been growing in other countries and " 80 plus" pool of countries gradually accepts new members. This example shows how changes in social and economic factors can influence population life expectancy.

The existing situation in the USA is quite different. The country has the highest GDP in the world and the highest expenses on public healthcare, both in absolute and relative values. But despite all that, life expectancy has not yet exceeded 80 years, and it has been steadily declining over the recent years. In scientific literature the phenomenon is now called 'the American paradox" [16]. Recent research that focused on life expectancy and population mortality in the USA reveled that an increase in overall mortality was mostly caused by such reasons as drugs overdose, alcohol abuse, suicides, and injuries. A basic risk group is loweducated employable men and women that live in rural areas or economically unfavorable regions [17]. Other research has revealed that the USA have the lowest ratio between expenses on social services and expenses on healthcare among all OECD countries [18-20].

We have discussed how socioeconomic determinants influence population life expectancy on the examples of events and situations in Russia and the USA; life quality and living standards that have direct influence on population lifestyle seem to make the most significant contribution into diseases occurrence and an increase in number of death cases.

In particular, "INTERHEART", a wellknown examination on risk factors causing cardiovascular diseases (CVD) that account for the greatest number of death cases all over the world, revealed that there were several reasons that made the primary contribution into CVD occurrence and deterioration; they are dislipoproteinemia, smoking, hypertension, diabetes, abdominal obesity, psychosocial factors, low consumption of vegetables and fruit, and low physical activity [21]. All the abovementioned reasons are modified risk factors and each of them often depends on a person's social and economic status; and these statuses can be quite different due to a social gradient in a society [22].

Inequality in education, incomes, and occupational status has its effects on difference in mortality and morbidity in population groups that are different as per these parameters [23, 24]. Besides, education is a significant component here as a level of future incomes will depend on it. Education also influences a person's awareness about risk factors and possible ways to preserve and improve his or her health. There are several research works revealing that mortality tends to be lower among well-educated people and LEB tends to be higher in countries with a higher fraction of educated people [25-29].

Together with education, population incomes also have significant influence on LEB. First of all, cash that is available to households allows people to buy more qualitative products and services and create favorable conditions for life and rest [30, 31]. According to some data, children who live in families with low social and economic status are more prone to cardiovascular system diseases in their adult 
life including ischemic heart disease (IHD) and cardiac infarction [32]. Insufficient incomes produce grave effects on males' health as men are more prone to various deviant behaviors such as alcohol intake, smoking, violence and injuries [33].

A person's lifestyle is known to make the greatest contribution into his or her health state [34]. Smoking, alcohol intake, insufficient consumption of vegetables and fruit, and high prevalence of obesity leads to a decrease in LEB among population as a whole [35-38]. Factors related to social tension or psychosocial stress such as unlawful actions including murders, divorces, and unemployment also exert negative influence on population mortality and LEB [39].

We should stress that all the abovementioned risk factors are fully modified and basically depend on relevant state policy regarding economy, social security, and public healthcare both in a country as a whole and on a regional level. Such policy should be based on well-predictable parameters and, among other things, on applying modern techniques for assessing health risks [40].

A regional aspect in demographic issues is especially relevant for the RF as there are substantial differences between the regions in the country as regards both social and economic parameters and life expectancy; in 2017 the difference between the maximum and the minimum LEB in the RF regions amounted to more than 15 years (66.1 in Chukotka Autonomous Area and 81.59 in Ingushetia).

Despite numerous research works that focused on searching for a correlation between social and economic status and LEB both in the RF and abroad, it is still unclear how social and economic determinants influence public and individual health. But at the same time, even given uncertainties in estimations, such factors can be significant proxy-variables that allow predicting LEB taking into account differentiated nature of spatial and time distribution that is typical for social and economic risk factors.

Our research goal was to examine regionally differentiated social and economic determinants and a potential for a growth in life expectancy in the RF related to such determinants.
Data and methods. In our research we considered a hypothesis that there was a direct or inverse regular cause-and-effect correlation between life expectancy at birth (whole population, males, and females as dependent variables) and social and economic determinants (risk factors as independent variables, predictors or regressors). To build up and analyze regression models, we took statistical data collected in 2010-2017 in 85 RF regions; all the data were obtained from official sources such as reports issued by the Federal State Statistics Service (economic parameters, basic food products consumption, alcohol sales, education, employment and unemployment, housing conditions, psychosocial stress, and indirect parameters showing physical activity of population); statistical reports issued by Rospotrebnadzor No. 18 "Data on sanitary situation in RF regions" (a fraction of children who had hot meals at least once a day). Totally, our analysis included 85 socioeconomic parameters that were combined into several groups: public healthcare; economic parameters; basic food products consumption; alcohol sales; a fraction of children who have hot meal at least once a day; employment; parameters related to housing conditions; psychosocial stress; indirect parameters showing physical activity of population; population structure.

We calculated model parameters and checked their adequacy with standard regression analysis applying Statistica 10.0 software package for statistical data analysis. Statistical hypotheses regarding regression coefficients in case parameters were distributed normally were checked with Student's t-test. Models adequacy was checked with dispersion analysis performed with Fischer's test and significance level being 0.05 .

To examine occurrence of numerous correlations between socioeconomic parameters and a decrease in initial data dimensions, we applied exploratory factor analysis; we built correlations as per the following chain: "socioeconomic parameters - generalized factors LEB". Sequential creation of correlation variables matrix, factors extraction via least-square procedure and finding eigenvalues of factors 
with consequent Kaiser Criterion application (eigenvalues criterion) allowed us to reduce a number of factors up to 20 . To obtain values for burdens of variables on factors, we applied orthogonal rotation that allowed excluding mutual influences produced by factors. These approaches allowed us to calculate quantitative changes in LEB under preset changes in examined socioeconomic parameters.

Our algorithm for creating correlations as per "socioeconomic parameters - generalized factors - LEB" chain included the following basic stages:

- setting predicted socioeconomic parameters via making changes into initial values by a scenario per cent (for example, $10 \%, 5 \%$, or $1 \%$ );

- calculating a difference between predicted and actual value of a socioeconomic parameter;

- recovering data for specific data series as per an algorithm that is given below;

- calculating mean values of a parameter and standard deviation for observation series;

- calculating standardized difference between predicted and actual value of a socioeconomic parameter;

- calculating changes in generalized factors associated with changes in a socioeconomic parameter, taking into account multiple regression coefficient "socioeconomic factors life expectancy";

- summing up all the values of changes in LEB obtained at the previous stage associated with changes in a socioeconomic parameter;

- ranking all the socioeconomic parameters as per their contributions made into changes in LEB.

The difference between predicted and actual values of a socioeconomic parameter was calculated as per the formula (1):

$$
\Delta D=D^{\prime}-D,
$$

where $\Delta D$ is the difference between a predicted and actual value of a socioeconomic parameter; $D^{\prime}$ is a predicted value of a socioeconomic parameter; $D$ is an actual value of a socioeconomic parameter.

When performing factor analysis, we recovered missing data in an observation series according to the following algorithm: if there were no data in an examined year as regards a given parameter in a specific RF region, we took data collected in the previous year; should there be no data collected in the previous years, we took an average value for an observation series.

We calculated average values and standard deviations for each filled (recovered) data series. The standardized difference between predicted and actual values of socioeconomic parameters was determined as per the following formula (2):

$$
\begin{gathered}
\Delta d=d^{\prime}-d= \\
=\frac{D^{\prime}-\bar{D}}{D_{s}}-\frac{D-\bar{D}}{D_{s}}=\frac{D^{\prime}-D}{D_{s}}=\frac{\Delta D}{D_{s}},
\end{gathered}
$$

where $\Delta d$ is the standardized difference between a predicted and an actual value of a parameter; $d^{\prime}$ is a standardized predicted value of a parameter; $d$ is a standardized actual value of a parameter; $\bar{D}$ is an average value of a parameter with recovered data; $D_{s}$ is a standard deviation in a parameter with recovered data.

We calculated changes in generalized factors associated with changes in a socioeconomic parameter as per the following formula (3):

$$
\Delta F_{i}=\Delta d \cdot k_{i},
$$

where $\Delta F_{i}$ is a change in the $i$-th generalized factor associated with a change in a socioeconomic parameter; $k_{i}$ is a factor coefficient for the $i$-th generalized factor (determined as per factor analysis results).

A change in life expectancy associated with a change in a socioeconomic parameter was determined via summing up all the products of changes in generalized factors multiplied by relevant "socioeconomic parameters LEB" multiple regression coefficients as per the following formula (4):

$$
\Delta Z=\Delta F_{i} \cdot b_{i},
$$

where $\Delta Z$ is a change in life expectancy associated with a change in a socioeconomic parameter given in years; $b_{i}$ is a coefficient before the $i$-th factor in "socioeconomic factors LEB" multiple regression. 
Exploratory factor analysis allowed obtaining a factor burden matrix that totally included 20 factors. Cumulative per cent of explained variance amounted to $81.9 \%$. Formulas (3) and (4) were applied to calculate quantitative changes in LEB associated with a change in each examined socioeconomic parameter. We give an example of calculating a change in life expectancy depending on a $10.0 \%$ change in values of socioeconomic parameters; in this calculation parameters that led to an increase in LEB were raised by $10.0 \%$, and those that decreased LEB were reduced by $10.0 \%$. To perform aggregated analysis, we combined all the examined socioeconomic parameters into several factor groups: economic parameters; basic food products consumption; alcohol sales; education; employment and unemployment; housing conditions; psychosocial stress; indirect parameters showing physical activity of population.

We divided RF regions into several clusters according to their socioeconomic parameters and LEB applying a multi-dimensional statistical procedure, namely cluster analysis with k-medians clustering. Parameter values in clusters were compared as per their average cluster values.

Basic results. Linear correlation-regression analysis allowed us to obtain 201 authentically significant models. We analyzed influence exerted by socioeconomic determinants on LEB of female population and revealed the most significant factors as per explained variance coefficient; these factors given in the descending order are as follows: a number of registered crimes per 100,000 people $\left(a_{x}=-0.002\right.$; $\left.b=79.16 ; p<0.05 ; r=-0.36 ; R^{2}=0.13\right)$; a fraction of employed population with high education $\left(a_{x}=0.16 ; b=71.03 ; p<0.05 ; r=0.25\right.$; $\left.R^{2}=0.063\right)$; consumption of vegetables and melons in $\mathrm{kg} /$ year per 1 consumer $\left(a_{x}=0.042\right.$; $\left.b=71.64 ; p<0.05 ; r=0.23 ; R^{2}=0.053\right)$; specific weight of housing equipped with centralized water supply $\left(a_{x}=0.056 ; b=71.38\right.$; $\left.p<0.05 ; r=0.22 ; R^{2}=0.049\right)$. LEB of male population was primarily influenced by a number of registered crimes per 100,000 people $\left(a_{x}=-0.004 ; b=70.74 ; p<0.05 ; r=-0.66\right.$;
$R^{2}=0.43$ ); marriages to divorces ratio (a number of divorces per 1,000 marriages) ( $a_{x}=-0.009$; $\left.b=69.93 ; p<0.05 ; r=-0,34 ; R^{2}=0.11\right)$; consumption of vegetables and melons in $\mathrm{kg} /$ year per 1 consumer $\left(a_{x}=0.069 ; b=57.93 ; p<0.05\right.$; $\left.r=0.4 ; R^{2}=0.16\right)$; consumer expenses per capita, rubles per month $\left(a_{x}=0.0002 ; b=62.02\right.$; $\left.p<0.05 ; r=0.3 ; R^{2}=0.09\right)$; a fraction of employed population with high education $\left(a_{x}=0.314\right.$; $\left.b=55.33 ; p<0.05 ; r=0.52 ; R^{2}=0.28\right)$. The most significant models for LEB of the overall population were a number of registered crimes per 100,000 people $\left(a_{x}=-0.003 ; b=75.41\right.$; $\left.p<0.05 ; r=-0.65 ; R^{2}=0.42\right)$; consumption of vegetables and melons in $\mathrm{kg} /$ year per 1 consu$\operatorname{mer}\left(a_{x}=0.062 ; b=64.23 ; p<0.05 ; r=0.41\right.$; $\left.R^{2}=0.17\right)$; a fraction of employed population with high education $\left(a_{x}=0.26 ; b=62.56\right.$; $\left.p<0.05 ; r=0.5 ; R^{2}=0.25\right)$; specific weight of housing equipped with centralized water supply $\left(a_{x}=0.082 ; b=63.89 ; p<0.05 ; r=0.39\right.$; $\left.R^{2}=0.16\right)$.

Cluster analysis allowed us to distribute all the RF regions into 4 major groups (clusters) that had their specific socioeconomic parameters; the $1^{\text {st }}$ cluster was made up of 2 regions; the $2^{\text {nd }}, 6$ regions; the $3^{\text {rd }}, 31$ regions; and the $4^{\text {th }}, 46$ regions (Figure 1 ).

The $1^{\text {st }}$ cluster includes two RF regions, the Nenets Autonomous Area and the Yamal Nenets Autonomous Area. Average LEB value for this cluster amounts to $72.53 \pm 1.01$ years and is among the highest ones in the country. This cluster has high values of socioeconomic parameters such as investments into fixed assets (average cluster value is $2,623,477$ rubles) and gross regional product $(4,745,909$ rubles) per capita; but at the same time average registered unemployment in this cluster is comparatively high $(1.7 \%)$. Provision with doctors (50.2 per 10,000 people) and places in hospitals $(85.25$ per 10,000$)$ is higher in this cluster than in the country on average (47.5 and 80.5 per 10,000 people respectively).

We have analyzed basic food products consumption $^{7}$ and revealed that people living

\footnotetext{
${ }^{7}$ Here and hereinafter quantity of food products consumed by population and given in kilograms per year per 1 consumer (kg/year per 1 consumer) was estimated basing on recommendations given by the RF Public Healthcare Ministry, The Order No. 614 dated August 19, 2016. "On Approval on the Recommendations on rational standards for food products consumption that conform to contemporary requirements to healthy nutrition".
} 


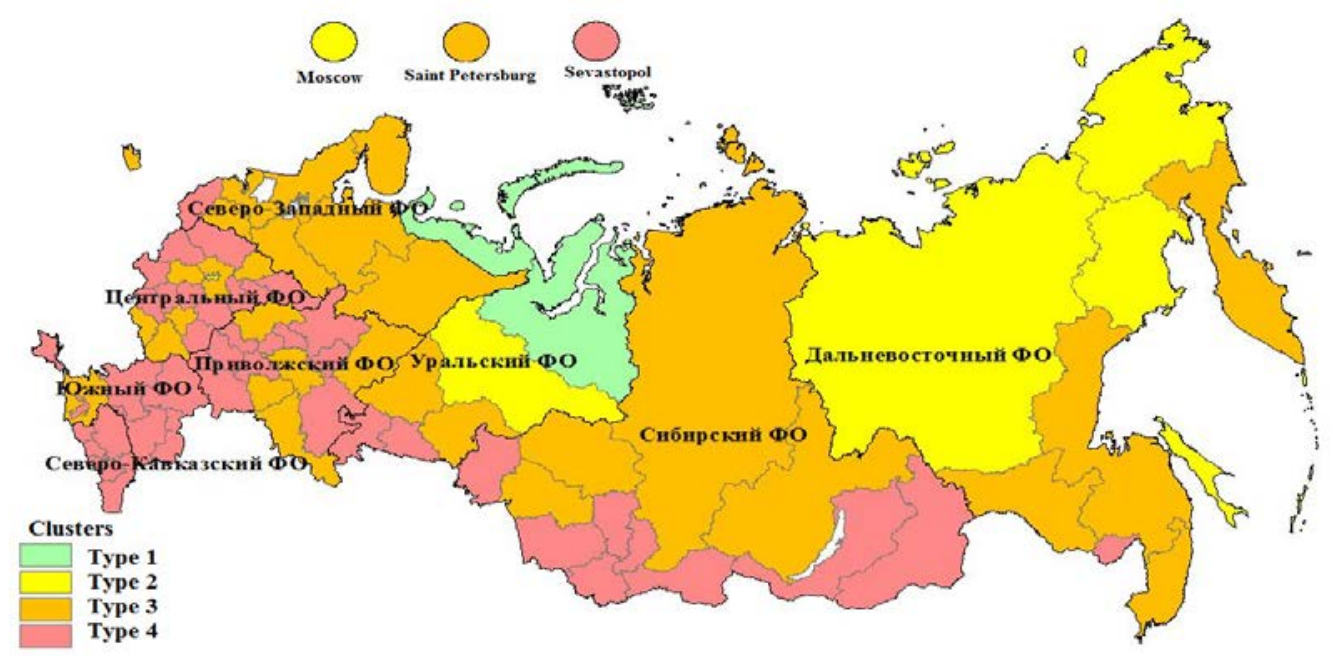

Figure 1. RF regions distributed into 4 clusters as per socioeconomic parameters

in this cluster don't consume sufficient quantities of vegetables $(86.65 \mathrm{~kg} /$ year per 1 consumer, the standard being $140 \mathrm{~kg} / \mathrm{year}$ ) and fruit $(67.25 \mathrm{~kg} /$ year per 1 consumer, the standard being $100 \mathrm{~kg} /$ year); at the same time, fish and fish products $(36.15 \mathrm{~kg} /$ year per 1 consumer, the standard being $22 \mathrm{~kg} / \mathrm{year})$ and sugar and confectionary $(38.3 \mathrm{~kg} /$ year per $1 \mathrm{con}-$ sumer, the standard being $24 \mathrm{~kg} /$ year) are consumed in quantities that exceed recommended standards. This cluster has one of the highest alcohol sales volumes (vines and low-alcohol drinks) per capita (9.5 and 0.95 liter per capita accordingly). Population structure in the cluster is characterized with high specific weight of young $(24.4 \%)$ and employable $(60.55 \%)$ population. Housing conditions such as a specific weight of housing equipped with centralized water supply $(80.6 \%)$ and sewage $(75.15 \%)$ are poorer than on average in the country $(82.4 \%$ and $77.6 \%$ respectively). A specific weight of housing that has central heating is the highest among all the clusters and it is most probably due to climatic conditions and geographic locations of the regions. At the same time a specific weight of dilapidated housing is the highest in the cluster and amounts to $6.05 \%$. Besides, the crime rate is also the highest in this cluster as it amounts to $1,645.5$ registered crimes per 100,000 people. Therefore, high LEB in the cluster is mostly due to economic parameters and factors that could probably result in a decrease in LEB are high crime rate, alcohol consumption, and poor housing conditions.

The $2^{\text {nd }}$ cluster consists of $6 \mathrm{RF}$ regions; they are Moscow City, the Khanty-Mansi Autonomous Area, Yakutia, Magadan region, Sakhalin, and Chukotka Autonomous Area. Average cluster LEB amounts to $71.51 \pm 1.65$ years. Economic parameters in the cluster including average cash incomes per capita $(53,400.0$ rubles per month) and consumer expenses $(32,280.67$ rubles per month) are higher than on average in the country $(31,422.0$ and $23,806.0$ rubles per month respectively). Average cluster unemployment is the lowest ( $4.3 \%$ on average annually) as per data obtained via sampling examinations of employable population. The cluster also has the highest values of healthcare-related parameters; for example, a number of medical personnel with all specialties amounts to $61.25 \%$ per 10,000 people. People living in the $2^{\text {nd }}$ cluster don't consume sufficient quantities of vegetables and melons $(85.6 \mathrm{~kg} /$ year per 1 consumer), potatoes ( $46.9 \mathrm{~kg} /$ year per 1 consumer), eggs (210 eggs/year per 1 consumer), milk and milk products $(239.4 \mathrm{~kg} /$ year per 1 consumer), and butter $(10.7 \mathrm{~kg} /$ year per 1 consumer). Alcohol sales for several types of alcohol drinks (vodka and liquor, sparkling wines, beer and beer-based drinks) per capita are also among the highest in the country $(9.481,2.21$, and 57.51 per capita respectively).

The cluster has the highest fraction of urban population $(84.17 \%)$ and the highest divorce 
rate among married families (634.8 divorces per 1,000 marriages). Housing conditions such as specific weight of housing equipped with centralized water supply $(87.43 \%)$ and sewage $(86.1 \%)$ are the best among clusters. This cluster also has comparatively high crime rate (1,579.3 per 100,000 people) and a rather big share of housing that can be considered dilapidated $(2.77 \%)$. Therefore, factors that allow keeping LEB at its existing level are economic parameters that are higher than in the country on average, low unemployment rate, as well as high value of healthcare-related parameters. Risk factors in the cluster are high alcohol sales per capita, divorces rate, and crime rate.

The $3^{\text {rd }}$ cluster comprises $31 \mathrm{RF}$ regions, namely Belgorod, Voronezh, Kaluga, Lipetsk, Moscow (region), Yaroslavl, Karelia, the Komi Republic, Arkhangelsk, Vologda, Kaliningrad, Leningrad (region), Murmansk, Novgorod, Saint Petersburg (city), Krasnodar, Tatarstan, Perm, Nizhniy Novgorod, Orenburg, Samara, Sverdlovsk (region), Tyumen, Krasnoyarsk, Irkutsk, Novosibirsk, Tomsk, Kamchatka, Primorye, Khabarovsk, and Amur regions. Average cluster LEB amounts to $71.68 \pm 0.26$ years. A peculiar feature of the cluster is that most analyzed parameters correspond to their average country values. For example, economic parameters such as cash incomes per capita $(30,410.23$ rubles per month) and gross regional product per capita $(454,838$ rubles $)$ are similar to average country values $(31,422.0$ rubles per months and 472,161.9 rubles accordingly). Registered unemployment is the lowest among all clusters $(1.05 \%)$. Healthcare-related parameters are also quite comparable with average country ones; for example, number of doctors with all specialties amounts to $48.8 \%$ per 10,000 people $(47.5 \%$ on average in the country).

Basic food products consumption is, in general, in conformity with standards recommended by the RF Public Healthcare Ministry (potatoes are consumed in a quantity equal to $59.5 \mathrm{~kg} /$ year per 1 consumer; in the RF, $59.4 \mathrm{~kg} /$ year per 1 consumer; fruit and berries, $73.1 \mathrm{~kg} /$ year per 1 consumer, in the $\mathrm{RF}$, $73 \mathrm{~kg} /$ year per 1 consumer). Alcohol sales are also comparable with average country levels (cognac, 0.84 1, in the RF, 0.7 1; sparkling wines, 1.31 , in the RF, 1.21 ). Population in the cluster has a rather high share of people who are beyond their employable age (elderly ones, $25.5 \%)$. Housing conditions in the $3^{\text {rd }}$ cluster are also comparable to average country ones (housing equipped with centralized water supply accounts for $81.1 \%$, in the RF, $82.4 \%$ ). Crime rate $(1,561 \%$ \% married families (614.1 per 1,000 marriages) are higher than on average in the country $(1,402.0 \% 0000$ and $582.0 \%$ accordingly). Therefore, LEB in the cluster is supported by low registered unemployment and basic food products consumption being the closest to recommended standards among all clusters. Risk factors are crime rate and divorces rate among married families.

The $4^{\text {th }}$ cluster includes $46 \mathrm{RF}$ regions, namely Bryansk, Vladimir, Ivanovo, Kostroma, Kursk, Orel, Ryazan, Smolensk, Tambov, Tver, Tula, Pskov, Adygei Republic, Kalmykia, Crimea, Astrakhan, Volgograd, Rostov, Sevastopol, Dagestan, Ingushetia, Kabardino-Balkaria, Karachai-Cherkess, North Ossetia, Chechnya, Stavropol, Bashkortostan, Mari (y) El Republic, Mordovia, Udmurtia, Chuvashia, Kirov, Penza, Saratov, Ulyanovsk, Kurgan, Chelyabinsk, Altai Republic, Buryatia, Tyva, Khakassia, Altai region, Transbaikalia, Kemerovo, Omsk, and the Jewish Autonomous Region. Average cluster LEB amounts to $72.39 \pm 0.36$ years. Economic parameters and healthcare-related parameters in the regions in this cluster are among the lowest in the RF (cash incomes per capita amount to only 22,605.37 rubles per month). Basic food products consumption, excluding bread and groceries $(106.12 \mathrm{~kg} /$ year per 1 consumer with the standard being $97 \mathrm{~kg} /$ year per 1 consumer), corresponds to average country levels. Alcohol sales per capita are the lowest in this cluster (vodka, 4.58 1; wines, 5.321 per capita). Specific weight of urban population is rather low in these regions $(64.9 \%)$ as well as fraction of employable population (55.1\%). Housing conditions are the poorest among all clusters (only $76.19 \%$ of the overall housing is 
equipped with centralized water supply). But at the same time the crime rate is the lowest in the cluster $(1,379.1 \%$ \%000) as well as divorces rate $(578.37 \%$ ).

Therefore, LEB in the cluster remains at the same level due to low crime and divorces rates, low share of dilapidated housing as well as the lowest alcohol sales among all clusters. Risk factors that can cause a decrease in LEB are low economic parameters, low healthcare-related parameters, and poor housing conditions.

Exploratory factor analysis allowed us to reveal predicted quantitative changes in life ex- pectancy at birth (for the overall population) associated with changes in socioeconomic parameters; it confirmed the results of previously performed correlation-regression and cluster analysis. The Table contains the results of $10.0 \%$ scenario changes in socioeconomic parameters. For example, should there be a change in healthcare-related parameters such as a $10.0 \%$ increase in a number of medical personnel per 10,000 people, and, accordingly, a $10.0 \%$ decrease in a burden on public healthcare workers (a number of people per 1 doctor), it will lead to 8.3 days increase in LEB of the overall population (Table).

Table

Potential for a growth in life expectancy of the RF population determined by a socioeconomic factor (a scenario envisages a $10.0 \%$ change in independent variables)

\begin{tabular}{|c|c|c|c|}
\hline $\begin{array}{c}\text { Groups } \\
\text { of parameters }\end{array}$ & $\begin{array}{c}\text { Increase } \uparrow / \\
\text { decrease } \downarrow \\
\text { in a parameter }\end{array}$ & Parameter & $\begin{array}{c}\text { An increase } \\
\text { in LEB } \\
\text { given in days }\end{array}$ \\
\hline \multirow{2}{*}{$\begin{array}{l}\text { Healthcare- } \\
\text { related } \\
\text { parameters }\end{array}$} & $\uparrow$ & $\begin{array}{l}\text { A number of doctors with all specialties per } 10,000 \text { population, people } \\
\text { (taken at the end of a year) }\end{array}$ & 8.29 \\
\hline & $\downarrow$ & $\begin{array}{l}\text { Burden on public healthcare workers (taken at the end of a year, number of } \\
\text { people per } 1 \text { doctor) * }\end{array}$ & 8.2 \\
\hline \multirow{11}{*}{$\begin{array}{l}\text { Economic } \\
\text { parameters }\end{array}$} & $\uparrow$ & Consumer expenses per capita, rubles per month & 28.12 \\
\hline & $\uparrow$ & Average cash incomes per capita, rubles per month & 13.17 \\
\hline & $\downarrow$ & $\begin{array}{l}\text { A specific weight of population with their cash incomes being lower than the } \\
\text { living wage (per cent of the total population in a region), } \%\end{array}$ & 13.37 \\
\hline & $\uparrow$ & Gross regional product per capita, rubles & 3.77 \\
\hline & $\uparrow$ & Investments into fixed assets per capita (given in actual prices) & 1.97 \\
\hline & $\downarrow$ & $\begin{array}{l}\text { Unemployment rate as per data obtained via sampling examinations of em- } \\
\text { ployable population (average annual), } \%\end{array}$ & 0.51 \\
\hline & $\downarrow$ & $\begin{array}{l}\text { Registered unemployment rate as per data provided by the Federal Service } \\
\text { on Labor and Employment (taken at the end of a year), } \%\end{array}$ & 0.4 \\
\hline & $\uparrow$ & Living wage (Employable population), rubles & 4.73 \\
\hline & $\uparrow$ & Living wage (children), rubles & 1.5 \\
\hline & $\uparrow$ & Living wage (retired), rubles & 3.29 \\
\hline & $\uparrow$ & Living wage (overall population), rubles & 3.26 \\
\hline \multirow{7}{*}{$\begin{array}{c}\text { Basic food } \\
\text { products } \\
\text { consumption } \\
\text { in house- } \\
\text { holds }\end{array}$} & $\downarrow$ & $\begin{array}{l}\text { Basic food products consumption in households (meat and meat products; } \\
\mathrm{kg} / \text { year per } 1 \text { consumer) }\end{array}$ & 3.87 \\
\hline & $\uparrow$ & $\begin{array}{l}\text { Basic food products consumption in households (eggs, units; kg/year per } \\
1 \text { consumer) }\end{array}$ & 3.68 \\
\hline & $\uparrow$ & $\begin{array}{l}\text { Basic food products consumption in households (bread and groceries; } \\
\mathrm{kg} / \text { year per } 1 \text { consumer) }\end{array}$ & 2.95 \\
\hline & $\uparrow$ & $\begin{array}{l}\text { Basic food products consumption in households (vegetable oil and other fats; } \\
\mathrm{kg} / \text { year per } 1 \text { consumer) }\end{array}$ & 0.88 \\
\hline & $\uparrow$ & $\begin{array}{l}\text { Basic food products consumption in households (potatoes; } \mathrm{kg} / \mathrm{year} \text { per } \\
1 \text { consumer) }\end{array}$ & 12.55 \\
\hline & $\uparrow$ & $\begin{array}{l}\text { Basic food products consumption in households (vegetables and melons; } \\
\mathrm{kg} / \text { year per } 1 \text { consumer) }\end{array}$ & 11.32 \\
\hline & $\uparrow$ & $\begin{array}{l}\text { Basic food products consumption in households (milk and milk products; } \\
\mathrm{kg} / \text { year per } 1 \text { consumer) }\end{array}$ & 11.05 \\
\hline
\end{tabular}




\begin{tabular}{|c|c|c|c|}
\hline \multirow{6}{*}{$\begin{array}{l}\text { Alcohol } \\
\text { sales }\end{array}$} & $\downarrow$ & Alcohol sales to population (cognac) & 5.67 \\
\hline & $\downarrow$ & Alcohol sales to population (beer and beer-based beverages, liters per capita) & 14.19 \\
\hline & $\downarrow$ & $\begin{array}{l}\text { Alcohol sales to population (wines (without sparkling wines and champagne, } \\
\text { liters per capita) }\end{array}$ & 10.86 \\
\hline & $\downarrow$ & Alcohol sales to population (vodka and liquors, liters per capita) & 10.32 \\
\hline & $\downarrow$ & Alcohol sales to population (sparkling wines and champagne, liters per capita) & 6.57 \\
\hline & $\downarrow$ & $\begin{array}{l}\text { Alcohol sales to population (low alcohol drinks (ethyl spirit contents not } \\
\text { exceeding } 9 \% \text { ), liters per capita) }\end{array}$ & 1.96 \\
\hline \multirow{2}{*}{$\begin{array}{c}\text { Children } \\
\text { provided } \\
\text { with hot } \\
\text { meals }\end{array}$} & $\uparrow$ & $\begin{array}{l}\text { Hot meals (lunch) provided for students at vocational education establish- } \\
\text { ments, \% }\end{array}$ & 12.13 \\
\hline & $\uparrow$ & $\begin{array}{l}\text { Hot meals (breakfast and lunch) provided for schoolchildren studying } \\
\text { at } 1-11 \text { grades, } \%\end{array}$ & 2.92 \\
\hline \multirow{10}{*}{$\begin{array}{l}\text { Employment/ } \\
\text { unemploy- } \\
\text { ment among } \\
\text { population } \\
\text { with various } \\
\text { education }\end{array}$} & $\uparrow$ & A share of employed people aged 15-72 with high education, $\%$ & 36.02 \\
\hline & $\uparrow$ & A share of employed people aged $15-72$ with general secondary education, $\%$ & 7.33 \\
\hline & $\uparrow$ & A share of employed people aged 15-72 with vocational education, $\%$ & 5.37 \\
\hline & $\uparrow$ & A share of employed people aged 15-72 without general secondary education, $\%$ & 0.03 \\
\hline & $\uparrow$ & A share of unemployed people aged 15-72 with high education, $\%$ & 28.32 \\
\hline & $\downarrow$ & A share of unemployed people aged $15-72$ with basic secondary education, $\%$ & 13.68 \\
\hline & $\downarrow$ & A share of unemployed people aged 15-72 with vocational education, \% & 11.89 \\
\hline & $\downarrow$ & $\begin{array}{l}\text { A share of unemployed people aged } 15-72 \text { with vocational education for } \\
\text { highly qualified workers and clerks, } \%\end{array}$ & 7.01 \\
\hline & $\downarrow$ & A share of unemployed people aged 15-72 with general secondary education, $\%$ & 2.56 \\
\hline & $\downarrow$ & $\begin{array}{l}\text { A share of unemployed people aged 15-72 without basic secondary edu- } \\
\text { cation, \% }\end{array}$ & 3.08 \\
\hline \multirow{4}{*}{$\begin{array}{l}\text { Housing } \\
\text { conditions }\end{array}$} & $\uparrow$ & Specific weight of housing equipped with sewage, $\%$ & 18.9 \\
\hline & $\uparrow$ & Specific weight of housing equipped with central heating, $\%$ & 37.4 \\
\hline & $\uparrow$ & Specific weight of housing equipped with centralized water supply, $\%$ & 29.97 \\
\hline & $\downarrow$ & Specific weight of dilapidated housing, $\%$ & 0.63 \\
\hline \multirow{2}{*}{$\begin{array}{c}\text { Indirect } \\
\text { parameters } \\
\text { showing } \\
\text { physical } \\
\text { activity of } \\
\text { population }\end{array}$} & $\downarrow$ & Swimming pools (number of people per 1 swimming pool) & 0.87 \\
\hline & $\downarrow$ & $\begin{array}{l}\text { Open-air sport facilities (playgrounds and fields) number of people per } \\
1 \text { facility) }\end{array}$ & 6.6 \\
\hline \multirow{2}{*}{$\begin{array}{c}\text { Psychosocial } \\
\text { stress }\end{array}$} & $\downarrow$ & Marriages to divorces ratio (number of divorces per 1,000 marriages) & 29.38 \\
\hline & $\downarrow$ & A number of registered crimes per 100,000 people & 25.2 \\
\hline \multirow{2}{*}{$\begin{array}{c}\text { Population } \\
\text { structure }\end{array}$} & $\uparrow$ & People younger than employable age, $\%$ & 2.96 \\
\hline & $\uparrow$ & Males to females ratio (number of women per $1,000 \mathrm{men}$ )* & 103.98 \\
\hline & & Всего & 460,5 \\
\hline
\end{tabular}

Note: * means that this parameter was not included when summing a an expected change in life expectancy given in days

We have analyzed economic parameters and revealed that combined effects produced by average cash incomes, consumer expenses, gross regional product, investments into fixed assets per capita, unemployment rate and other parameters (Figure 2) can result in 74.09 days increase in LEB of the overall population. We have also determined that unemployment rate and specific weight of population with incomes being lower than living wage lead to a decrease in LEB of the overall population (13.8 days), and a rise in average cash incomes per capita, gross regional product, and investments into fixed assets make it increase by 18.91 days on average

Parameters that characterize people's lifestyle include basic food products consumption, energy value of a daily ration consumed in households, alcohol consumption, and a number of children provided with hot meals. We have established that a $10.0 \%$ increase in consumption of such products as eggs, bread and groceries, vegetable oil and other fats, potatoes, vegetables and melons, and milk and 


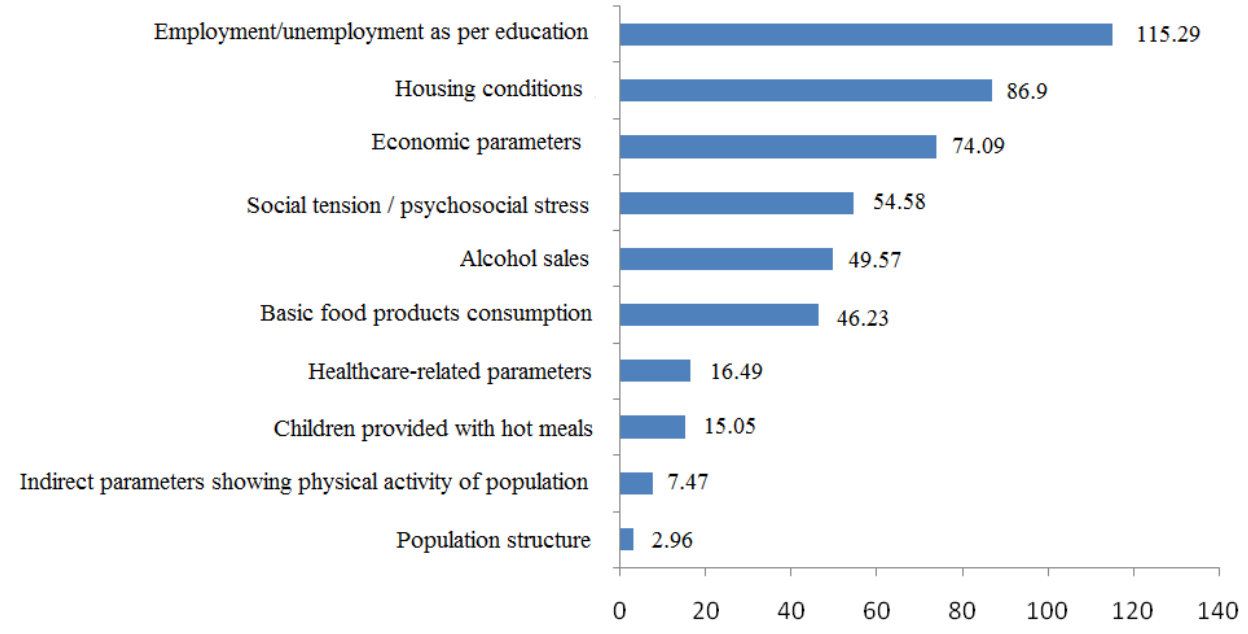

Figure 2. Predicted potential for a growth in life expectancy among the overall RF population determined by socioeconomic parameters (a scenario envisages a $10.0 \%$ rise), days

milk products lead to a rise in life expectancy; an increase in consumption of meat and meat products, on the contrary, results in a fall in LEB of the overall population. Total predicted growth in LEB of the overall population due to changes in basic food products consumption amounts to 42.23 days (Table).

We have obtained an inverse correlation between alcohol sales and LEB of the overall population. A $10.0 \%$-decrease in alcohol sales (most common alcohol drinks) makes LEB of the overall population grow by 49.57 days provided there are no any social consequences of such limitations.

There is a direct correlation between a number of children provided with hot meals, in particular, lunch provided for students attending vocational education establishments and breakfast and lunch provided for schoolchildren of 1-11 grades, and LEB of the overall population as a predicted growth in LEB amounts to 15.05 days.

We have analyzed parameters that characterize the social sphere (employment / unemployment taking into account education, housing conditions, indirect parameters showing physical activity of population, psychosocial stress, and population structure) and revealed that high education regardless of employment status leads to an increase in LEB of the overall population (Table). Besides, employed people with general secondary education, vocational education, and without basic secondary educa- tion increase LEB of the overall population whereas should they be unemployed, it results in a fall in it. An aggregated rise in LEB of the overall population caused by an increase in a number of employed people or their education level amounts to 115.29 days.

A $10.0 \%$-increase in parameters that characterize housing conditions such as specific weight of housing equipped with centralized water supply, central heating and sewage makes LEB of the overall population rise by 86.27 days. A $10.0 \%$-decrease in specific weight of dilapidated housing makes LEB of the overall population grow by 0.63 days.

Indirect parameters showing physical activity of population have been estimated via a number of people per 1 sport facility (swimming pools and open air grounds); they have a positive effect on LEB of the overall population (+7.47 days) should a number of sport facilities grow by $10.0 \%$.

We have determined that a $10.0 \%$-decrease in divorces rate and in crime rate leads to a predicted rise in LEB of the overall population that is equal to 54.58 days.

We have analyzed parameters that characterize population structure and revealed that an increase in males to females ratio (a number of women per 1,000 men) and a share of people younger than employable age makes LEB of the overall population grow by 103.98 and 2.96 respectively. It is well known that mortality among younger people and among women 
tends to be lower than among elderly people and men. And a vital task of the demographic policy in the country is to make a fraction of children grow.

Therefore, our calculations indicate that an aggregated increase in life expectancy of the overall RF population amounts to 460.5 days (1.3 years) provided there are relevant changes in the preset scenario conditions for analyzed socioeconomic determinants.

Discussion. Our research results have confirmed that there is a correlation between socioeconomic parameters and population life expectancy. We have shown that the most significant influence is exerted on LEB by economic parameters, lifestyle-related parameters, and parameters that characterize education and housing conditions. Obtained data are fully consistent with results obtained in other research in the sphere. Thus, it was established that an increase in number of people with high education would lead to a growth in LEB and it was probably due to better education providing a possibility to obtain more comprehensive information about potential health risks [24-29]. Besides, higher education often helps people get a more qualified, prestigious, and betterpaid job and it makes their life quality higher. And if a share of population with poor education grows, it results in a decrease in LEB, especially if people with poor education are unemployed. Therefore, people with poor education run greater health risks and, consequently, greater risks of a decrease in their LEB.

Average cash incomes per capita and consumer expenses allow making conclusions on welfare among population. Incomes rise provides an opportunity to buy more qualitative food products and better services and allows people to improve their life quality and living standard. Such parameters as gross regional product and investments into fixed assets also make LEB grow and reflect overall welfare of population in a region [30-32]. Opportunities that allow people to realize their potential to a great extent depend on the above-mentioned economic parameters.

Factors related to lifestyle also have their significance, especially structure and energy value of nutrition and alcohol sales. Food products consumption that corresponds to recommended standards especially regarding vegetables, milk products, potatoes, and eggs can result in a considerable growth in LEB [41]. Therefore, issues related to food safety, providing population with high quality and safe food products, and informing population about healthy nutrition play a significant role in the policy aimed at improving the demographic situation in the country.

An inverse correlation between alcohol sales in the RF regions and LEB highlights the significance of any policy aimed at regulating distribution of such products. Measures taken by the state and aimed at limiting a period of time when alcohol can be sold, complete ban on alcohol sales on certain days, excise-duties rise, implementation of the Unified State Automated Information System (USAIS) and other targeted activities will make for further improvement of the situation in the sphere.

Equipping housing with centralized water supply, sewage, and central heating leads to a considerable growth in LEB of the overall country population as it is confirmed by the results obtained in other research in the sphere [42]. Probably, more comfortable housing conditions when people are provided with centralized water supply, sewage, and central heating also allow achieving a decrease in population morbidity.

To sum up, our research allows us to make the following conclusions:

- socioeconomic determinants exert significant influence on life expectancy and are different in different regions a per a level of their potentiating or inhibiting effects on LEB;

- an aggregated increase in life expectancy of the overall RF population due to relevant changes in present scenario conditions $(10.0 \%)$ for the analyzed socioeconomic determinants can amount to 460.5 days (1.3 years);

- the greatest influence is exerted on life expectancy by the following socioeconomic parameters: employment / unemployment (115.29 days); housing conditions (86.9 days); economic parameters (74.09 days); psychosocial 
stress (54.58 days); alcohol sales (49.57 days); basic food products consumption (46.23 days).

Our research has covered influence exerted on life expectancy only by socioeconomic factors data on which are collected by official statistical authorities. We plan to focus our further research on examining impacts exerted on life expectancy of the RF population by other modifying environmental factors.
Gratitude. The authors are deeply grateful to experts of the Federal Scientific Center for Medical and Preventive Health Risk Management Technologies: M.R. Kamaltdinov, the Candidate of Physical and Mathematical Sciences; M.Yu. Zinker, and $\mathrm{S}$.Yu. Balashov for their assistance rendered in completing this paper.

Funding. The research was not granted any financial support.

Conflict of interests. The authors declare there is no any conflict of interests.

\section{References}

1. Reiting stran mira po urovnyu prodolzhitel'nosti zhizni [World countries rated as per life expectancy index]. Gumanitarnyi portal. Available at: https:/gtmarket.ru/ratings/life-expectancy-index/lifeexpectancy-index-info (01.12.2019) (in Russian).

2. World population prospects 2019. Department of Economic and Social Affairs. Available at: https://population.un.org/wpp/DataQuery/ (01.12.2019).

3. Poslanie Prezidenta Federal'nomu Sobraniyu [The RF President Message to the Federal Assembly]. Prezident Rossii. Available at: http://kremlin.ru/events/president/news/56957 (01.12.2019) (in Russian).

4. Tokudume S., Hashimoto S., Igata A. Life Expectancy and Healthy Life Expectancy of Japan: The Fastest Graying Society in the World. BMC Research Notes, 2016, vol. 9, no. 1, pp. 482-488. DOI: 10.1186/s13104-016-2281-2

5. Kontis V., Bennett J.E., Mathers C.D., Li G., Foreman K., Ezzati M. Future Life Expectancy in 35 Industrialised Countries: Projections With a Bayesian Model Ensemble. Lancet, 2017, vol. 1, no. 389 (10076), pp. 1323-1335. DOI: 10.1016/S0140-6736(16)32381-9

6. Omran A.R. The epidemiologic transition: A Theory of the Epidemiology of Population Change. The Milbank Memorial Fund Quarterly, 1971, vol. 49, no. 4, pp. 509-538. DOI: 10.1111/j.14680009.2005.00398.x

7. Famine and health. World Health Organization. Available at: https://www.who.int/emergencies/humanitarian-emergencies/famine/en/ (01.12.2019).

8. Kreatsoulas C., Ahand S.S. The impact of social determinants on cardiovascular disease. The Canadian Journal of Cardiology, 2010, vol. 26, pp. 8-13. DOI: 10.1016/s0828-282x(10)71075-8

9. Stevens J.W., Khunti K., Harvey R., Johnson M., Preston L., Woods H.B., Davies M., Goyder E. Preventing the Progression to Type 2 Diabetes Mellitus in Adults at High Risk: A Systematic Review and Network Meta-Analysis of Lifestyle, Pharmacological and Surgical Interventions. Diabetes Research and Clinical Practice, 2015, vol. 107, no. 3, pp. 320-331. DOI: 10.1016/j.diabres.2015.01.027

10. Briggs R., Kennelly S.P., O'Neill D. Drug treatments in Alzheimer's disease. Clinical Medicine Journal, 2016, vol. 16, no. 3, pp. 247-253. DOI: 10.7861/clinmedicine.16-3-247

11. Lebedeva-Nesevrya N.A., Barg A.O., Tsinker M.Yu., Kostarev V.G. Assessment of correlation between heterogeneous risk factors and morbidity among working population in Russian regions with different background of health formation. Health Risk Analysis, 2019, no. 2, pp. 91-100 (in Russian). DOI: $10.21668 /$ health.risk/2019.2.10.eng

12. Shetty P. Grey matter: ageing in developing countries. Lancet, 2012, vol. 7, no. 379, pp. 1285-1287. DOI: 10.1016/s0140-6736(12)60541-8

13. Global Health and Aging Report. World Health Organization, 2011, pp. 32.

14. Regiony Rossii. Sotsial'no-ekonomicheskie pokazateli. 2018: R32 Statisticheskii sbornik [The RF regions. Social and economic parameters. 2018: R32 Statistical data collection]. Moscow, Rosstat Publ., 2018, 1162 p. (in Russian).

15. Soveshchanie po voprosam modernizatsii pervichnogo zvena zdravookhraneniya [The meeting on issues related to modernizing the primary medical aid provided for the population]. Prezident Rossii. Available at: http://www.kremlin.ru/events/president/news/61340 (01.12.2019) (in Russian). 
16. Bradley E.H., Sipsma H., Taylor L.A. American health care paradox - high spending on health care and poor health. QJM: An International Journal of Medicine, 2017, vol. 110, no. 2, pp. 61-65. DOI: $10.1093 /$ qjmed/hcw187

17. Woolf S.H., Schoomaker H. Life expectancy and mortality rates in the United States, 2015-2017. JAMA, 2019, vol. 322, no. 20, pp. 1963-2015. DOI: 10.1001/jama.2019.16932

18. Dwyer-Lindgren L., Bertozzi-Villa A. Inequalities in Life Expectancy among Us Counties, 1980 to 2014. JAMA, 2017, vol. 177, no. 7, pp. 1003-1011. DOI: 10.1001/jamainternmed.2017.0918

19. Bradley E.H., Elkins B.R., Herrin J., Elbel B. Health and social services expenditures: associations with health outcomes. BMJ Quality and Safety, 2011, vol. 20, no. 10, pp. 826-831. DOI: 10.1136/bmjqs.2010.048363

20. Bradley E.H., Canavan M., Rogan E., Talbert-Slagle K., Ndumele C., Taylor L., Curry L.A. Variation In Health Outcomes: The Role Of Spending On Social Services, Public Health, And Health Care, 2000-09. Health Affairs (Project Hope), 2016, vol. 35, no. 5, pp. 760-768. DOI: 10.1377/hlthaff.2015.0814

21. Yusuf S., Hawken S., Ôunuu S., Dans T., Avezum A., Lanas F., McQueen M., Budaj A. [et al.]. Effect of potentially modifiable risk factors associated with myocardial infarction in 52 countries (the INTERHEART study): case-control study. Lancet, 2004, vol. 364, pp. 937-952. DOI: 10.1016/S01406736(04)17018-9

22. Wilkinson R., Marmot M. Social determinants of health: the solid facts $2^{\text {nd }}$ edition. WHO Library Cataloguing in Publication Data, 2004, 33 p.

23. Stringhini S., Carmeli C., Jokela M., Avendaño M., Muennig P., Guida F., Ricceri F., d'Errico A. [et al.]. Socioeconomic status and the $25 * 25$ risk factors as determinants of premature mortality: a multicohort study and meta-analysis of 1,7 million men and women. Lancet, 2017, vol. 25, no. 389, pp. 1229-1237. DOI: $10.1016 / \mathrm{S} 0140-6736(16) 32380-7$

24. Mackenbach J.P., Valverde J.R., Bopp M., Brønnum-Hansen H., Deboosere P., Kalediene R., Kovács K., Leinsalu M. [et al.]. Determinants of inequalities in life expectancy: an international comparative study of eight risk factors. Lancet Public Health, 2019, vol. 4, no. 10, pp. 529-537. DOI: 10.1016/S2468-2667(19)30147-1

25. Rogers R.G., Hummer R.A., Everett B.G. Educational differentials in US adult mortality: An examination of mediating factors. Social science research, 2013, vol. 42, no. 2, pp. 465-481. DOI: $10.1016 /$ j.ssresearch.2012.09.003

26. P'yankova A.I., Fattakhov T.A. Smertnost' po urovnyu obrazovaniya v Rossii [Mortality as per education in Russia]. Ekonomicheskii zhurnal VShE, 2017, vol. 21, no. 4, pp. 623-647 (in Russian).

27. Shul'gin S.G., Zin'kina Yu.V., Shcherbov S.Ya. Life expectancy of elderly in Russia depending on educational status. Demograficheskoe obozrenie, 2018, vol. 5, no. 1, pp. 25-38 (in Russian).

28. Bijwaard G.E., Van Poppel F., Ekamper P., Lumey L.H. Gains in Life Expectancy Associated with Higher Education in Men. PloS one, 2015, vol. 10, no. 10, pp. 1-18. DOI: 10.1371/journal.pone. 0141200

29. Mäki N., Martikainen P., Eikemo T., Menvielle G., Lundberg O., Ostergren O., Jasilionis D., Mackenbach J.P. Educational differences in disability-free life expectancy: a comparative study of longstanding activity limitation in eight European countries. Social Science and Medicine, 2013, vol. 94, pp. 1-8. DOI: 10.1016/j.socscimed.2013.06.009

30. Chetty R., Stepner M., Abraham S., Lin S., Scuderi B., Turner N., Bergeron A., Cutler D. The Association between Income and Life Expectancy in the United States, 2001-2014. JAMA, 2017, vol. 315, no. 16, pp. 1750-1766. DOI: 10.1001/jama.2016.4226

31. Mackenbach J.P., Bopp M., Deboosere P., Kovacs K., Leinsalu M., Martikainen P., Menvielle G., Regidor E., De Gelder R. Determinants of the magnitude of socioeconomic inequalities in mortality: A study of 17 European countries. Health and Place, 2017, vol. 47, pp. 44-53. DOI: 10.1016/j.healthplace.2017.07.005

32. Kamphuis C.B., Turrell G., Giskes K., Mackenbach J.P., Van Lenthe F.J. Socioeconomic inequalities in cardiovascular mortality and the role of childhood socioeconomic conditions and adulthood risk factors: a prospective cohort study with 17-years of follow up. BMC Public Health, 2012, vol. 12, pp. 1045. DOI: $10.1186 / 1471-2458-12-1045$

33. Södergren M. Lifestyle predictors of healthy ageing in men. Maturitas, 2013, vol. 75, pp. 113-117. DOI: 10.1016/j.maturitas.2013.02.011

34. Yurii Pavlovich Lisitsyn (k 80-letiyu so dnyarozhdeniya) [Yury Pavlovich Lisitsyn (to celebrate his $80^{\text {th }}$ anniversary)]. Ekologiya cheloveka, 2008, no. 3, pp. 48-49 (in Russian). 
35. Baars A.E., Rubio-Valverde J.R., Hu Y., Bopp M., Brønnum-Hansen H., Kalediene R., Leinsalu M., Martikainen P. [et al.]. Fruit and vegetable consumption and its contribution to inequalities in life expectancy and disability-free life expectancy in ten European countries. International Journal of Public Health, 2019, vol. 64, pp. 861-872. DOI: 10.1007/s00038-019-01253-w

36. Mackenbach J.P., Valverde J.R., Bopp M., Brønnum-Hansen H., Deboosere P., Kalediene R., Kovács K., Leinsalu M. [et al.]. Determinants of inequalities in life expectancy: an international comparative study of eight risk factors. Lancet Public Health, 2019, vol. 4, no. 10, pp. 527-537. DOI: 10.1016/S2468-2667(19)30147-1

37. Kuznetsova P.O. Smoking as a factor of reduced life expectancy in Russia. Demograficheskoe obozrenie, 2019, vol. 6, no. 3, pp. 31-57 (in Russian).

38. Kossova T.V., Kossova E.V., Sheluntsova M.A. Vliyanie potrebleniya alkogolya na smertnost' i ozhidaemuyu prodolzhitel'nost' zhizni v regionakh Rossii [Influence exerted by alcohol intake on mortality and life expectancy in Russian regions]. Ekonomicheskaya politika, 2017, vol. 12, no. 1, pp. 58-83 (in Russian).

39. Aburto J.M., Beltrán-Sánchez H. Upsurge of Homicides and Its Impact on Life Expectancy and Life Span Inequality in Mexico, 2005-2015. American Journal Public Health, 2019, vol. 109, no. 3, pp. 483-489. DOI: 10.2105/AJPH.2018.304878

40. Health risk analysis in the strategy of state social and economic development: monograph. In: G.G. Onishchenko, N.V. Zaitseva eds. Moscow, Perm, Publishing house of the Perm National Research Polytechnic University Publ., 2014, 686 p.

41. Zheng X.Y., Han Y.L., Guo C., Zhang L., Qiu Y., Chen G. Progress in research of nutrition and life expectancy. Biomedical and environmental sciences: BES, 2014, vol. 27, no. 3, pp. 155-161. DOI: $10.3967 /$ bes2014.036

42. Gulis G. Life expectancy as an indicator of environmental health. European Journal of Epidemiology, 2000, vol. 16, no. 2, pp. 161-165. DOI: 10.1023/a:1007629306606

Zaitseva N.V., Onishchenko G.G., Popova A.Yu., Kleyn S.V., Kiryanov D.A., Glukhikh M.V. Social and economic determinants and potential for growth in life expectancy of the population in the russian federation taking into account regional differentiation. Health Risk Analysis, 2019, no. 4, pp. 14-29. DOI: 10.21668/health.risk/2019.4.02.eng

Received: 16.10 .2019

Accepted: 20.12.2019

Published: 30.12.2019 